\title{
Fluorinated polymers: evaluation and characterization of structure and composition
}

\author{
Alexey A. Ivanov ${ }^{\mathrm{a}}$, Nikolay A. Belov ${ }^{\mathrm{a}, \mathrm{b}}$ \\ ${ }^{a}$ National Research Tomsk Polytechnic University, 30, Lenin Av., Tomsk 634050, Russian Federation, \\ ${ }^{\mathrm{b}}$ A.V. Topchiev Institute of Petrochemical Synthesis of Russian Academy of Sciences, 29, Leninskii Pr., \\ Moscow 119991, Russian Federation
}

$\triangle$ ivanovaa@tpu.ru

\begin{abstract}
The proposed review represents the systematic analysis of modern methods and approaches for the characterization and structural evaluation of fluorinated polymers that have found a wide application as materials for chemical processing, chemically resistant components and coatings, pharmaceutical and electrical packaging, biomedical equipment, etc. The chemical composition of the polymers (fluorine content, its distribution inside the fluorinated materials, chemical bonds, presence of oxygen-containing groups) substantially influences on the operation properties (chemical resistance, adhesive, cohesive, optical, dielectrical, thermal, barrier, gas permeation) of the final polymeric products. Hence, it was of particularly importance to bond the emergence of specific features with the presence of fluorine in the chemical structure of polymer by means of related analytical techniques. Namely, we focused on spectral (IR, UV-VIS, NMR, XPS, EPR), chemical (elemental analysis), Secondary-ion mass spectroscopic (SIMS) and microscopic (AFM, SEM-EDX) methods emphasizing their general consideration and limitations as well as application for the in-depth characterization.
\end{abstract}

Keywords: fluorinated polymers; X-ray photoelectron spectroscopy (XPS); nuclear magnetic resonance spectroscopy (NMR); secondary-ion mass spectroscopic (SIMS); atomic force microscopy (AFM); scanning electron microscopy (SEM); energy dispersive X-ray (EDX); infrared (IR) analysis.

For citation: Ivanov AA, Belov NA. Fluorinated polymers: evaluation and characterization of structure and composition. Journal of Advanced Materials and Technologies. 2021;6(2):144-155. DOI: 10.17277/jamt.2021.02.pp.144-155

\section{Фторированные полимеры: оценка, характеристика структуры и состава}

\author{
А. А. Иванов ${ }^{\mathrm{a}} \bowtie$, Н. А. Белов ${ }^{\mathrm{a}, \mathrm{b}}$

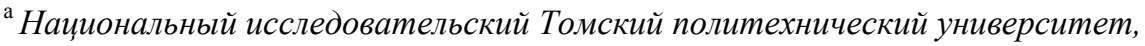 \\ пр. Ленина, 30, Томск 634050, Российская Федераџия, \\ ${ }^{\mathrm{b}}$ Институт нефтехимического синтеза им. А. В. Топчиева Российской академии наук, \\ Ленинский пр., 29, Москва 119991, Российская Федераџия \\ $\triangle$ ivanovaa@tpu.ru
}

\begin{abstract}
Аннотация: Предлагаемый обзор представляет собой систематический анализ современных методов и подходов к характеристике и оценке структуры фторированных полимеров, которые нашли широкое применение в качестве материалов для химических процессов, химически стойких компонентов и покрытий, фармацевтической и электрической упаковки, биомедицинского оборудования и т.д. Химический состав полимеров (содержание фтора, его распределение внутри фторированных материалов, химические связи, наличие кислородсодержащих групп) существенно влияет на эксплуатационные свойства (химическая стойкость, адгезионные, когезионные, оптические, диэлектрические, термические, барьерные, газовая проницаемость) конечных полимерных продуктов. Следовательно, особенно важно связать появление специфических особенностей с присутствием фтора в химической структуре полимера с помощью соответствующих аналитических методов. А именно, сосредоточились на спектральных (ИК, УФ-видимая, ЯМР, XPS, ЭПР), химических (элементный анализ), масс-спектроскопических (BИМС) и микроскопических (ACM, SEM-EDX) методах, рассматривая их основные возможности и ограничения для углубленной характеристики фторсодержащих полимеров.
\end{abstract}


Ключевые слова: фторированные полимеры; рентгеновская фотоэлектронная спектроскопия (РФЭС); ядерный магнитный резонанс (ЯМР); вторичная ионная масс-спектрометрия (ВИМС); атомно-силовая микроскопия (АСМ); сканирующая-электронная микроскопия (СЭМ); энергодисперсионный рентгеновский анализ; инфракрасная Фурье-спектроскопия.

Для цитирования: Ivanov AA, Belov NA. Fluorinated polymers: evaluation and characterization of structure and composition. Journal of Advanced Materials and Technologies. 2021;6(2):144-155. DOI: 10.17277/jamt.2021.02.pp.144-155

\section{Introduction}

Fluorine-containing polymers (FPs) are popular and irreplaceable products of large-scale chemistry. World production of fluorinated polymers in 2010 amounted to more than 200,000 tons, in $2012-$ 223,000 tons, while by 2022 it is predicted to double (to 405,000 tons) [1]. The high global demand for FPs is due to a unique combination of properties: chemical, electrochemical and thermal stabilities, oxygen resistance, low surface energy, low coefficient of friction, low high frequency-loss rates, low refractive indices, low permittivity etc. [1-4]. Such attractive macroscopic parameters of FPs are feasible owing to extremely high energy of $\mathrm{C}-\mathrm{F}$ bond $\left(478 \mathrm{~kJ} \cdot \mathrm{moL}^{-1}\right)$ for ordinary bonds and a lowest energy of intermolecular interactions (a solubility parameter of the perfluorinated compounds corresponds to ca. $12-13\left(\mathrm{~J} \cdot \mathrm{cm}^{-3}\right)^{1 / 2}$ whereas for the common hydrocarbons it does to $14-15\left(\mathrm{~J} \cdot \mathrm{cm}^{-3}\right)^{1 / 2}$. FPs are indispensable in many branches of science and technology: electronics [5, 6], energy [7-13], biomedical application [14, 15], membranes [16-21], coatings [22-25], - as materials for wire and cable insulation, industrial, architectural and multilayer barrier coatings, fuel tubing, hoses and fittings, seals, lighting, solar panels, automotive and mass transit cabling, optical fibers, etc. $[1,2,26]$. During the development and fabrication of the materials, it is extremely important to control the structure and composition of the resulting product. In this regard, the aim of this review is to consider and describe the methods for analysis of the structure and composition of FPs and changes associated with fluorination process. In order to maintain the operation properties of the products it is often sufficient to have a thin fluorinated layer over the material. Therefore, polymeric materials that are fluorinated by elemental fluorine in the gas- or liquid-phase regime are in the scope of the FPs under consideration. Such materials have a laminate structure with gradient of fluorine concentration along the normal to the surface. The thickness of the fluorinated layer usually is about several microns. The probing of these composite materials is also the aim of the review.

\section{Materials and methods}

\subsection{Elemental analysis}

The quantity of fluorine introduced to the material after direct fluorination can be estimated by combustion of sample in the Schoniger apparatus [27] and trapping of the combustion products in the absorbing solution. In the case of fluorination of polypropylene [28] and $\operatorname{poly}(p$-phenylene terephthalamide) [29], Maity et al. absorbed those products by mixture based on $\mathrm{Ce}$ (III) nitrate solution and the excess of the reagent was titrated by ethylenediamine tetraacetate. Despite the simplicity of the instrumental implementation, the oxygen flask technique faces problems of incomplete decomposition of highly fluorinated polymers and formation low molecular volatile compounds (tetrafluoromethane and others) which are not trapped in absorbing solutions. Here, the chemical resistance of fluorine-containing materials that is mostly provided by high dissociation energy of $\mathrm{C}-\mathrm{F}$ bond (ca. $485 \mathrm{~kJ} \cdot \mathrm{moL}^{-1}$ ) becomes their weakness. In order to improve fluorine recovery, Hruska and Lepot have decomposed the fluorinated polypropylene film with sodium peroxide [30] while Fan et al. performed the oxygen flask combustion with catalyst $\left(\mathrm{WO}_{3}+\mathrm{Sn}\right)$ [31]. Further detection of fluorine was performed by fluoride selective electrode [30,32].

A standard CHNSO method of high temperature combustion of sample in a stream of pure oxygen can be applied for indirect estimation of fluorine in the polymers. The fluorine content in a polymer assembled from the elements (carbon, hydrogen, nitrogen sulfur and oxygen) may be calculated as a residual weight after subsequent quantitative detection of the elements. This technique is a rapid, simple and low-cost analysis and has been successfully used for investigation of surface fluorinated conventional polyolefins [33-35] and other fluorine-containing polymers [36-38]. However, it also suffers from underestimation of carbon content due to the formation of thermostable low molecular fluorinated compounds in the combustion region [39]. 


\subsection{Spectroscopic techniques}

\subsubsection{IR spectroscopy}

Infrared spectroscopy is a traditional routine analytical technique that allows conducting structural analysis of both surface and bulk of polymeric materials. Each functional group absorbs infrared radiation at particular frequency. Three regions $\left(13,500-4,000 \mathrm{~cm}^{-1}\right.$ (near infrared), 4,000-400 $\mathrm{cm}^{-1}$ (middle infrared) and $400-10 \mathrm{~cm}^{-1}$ (far infrared)) compose the whole infrared range. Infrared spectrum of a polymer is an individual set of specific absorption bands that can be utilized to make polymer identification in "finger print" region [40-43]. Since fluorine-containing polymers, in particular perfluorinated polymers, are often solids and weakly soluble in organic solvents, among the wide diversity of infrared analytical procedures (transmission, specular reflection, multiple internal reflection, diffuse reflection, photoacoustic etc. [43]), attenuated total reflectance technique is the most popular one and allows one to measure samples rapidly without destruction and complicated preliminary preparation. Another advantage of the procedure is ability to vary the depth $d_{p}$ of penetration of IR radiation. It can be calculated as follows [44]:

$$
d_{p}=\frac{\lambda}{2 \pi n \sqrt{\sin ^{2} \theta-\left(\frac{n_{1}}{n_{2}}\right)^{2}}},
$$

where $\lambda$ and $\theta$ are wavelength and angle of incidence of IR radiation; $n_{1}, n_{2}$ are refractive indices of a polymer and an ATR-crystal, respectively.
The refractive indices of polymers and ATR-crystals belong to a narrow ranges of values: $1.3-1.8$ for polymers, 2.2-4.0 for ATR-crystals ( $\mathrm{ZnSe} 2.4$, $\mathrm{ZnS} \mathrm{2.2,} \mathrm{Silicon} \mathrm{3.4,} \mathrm{Ge} \mathrm{4.0,} \mathrm{diamond} \mathrm{2.4)} \mathrm{[44,} \mathrm{45].}$ Therefore, the variation of ATR-crystals and angle of incidence allows one to analyze polymers on the depths up to $0.7-15 \mu \mathrm{m}$ which is comparable with the thicknesses of the fluorinated polymeric layers $[46,47]$.

The ATR-IR technique was applied for investigation of the most fluorinated polymers (for instance, epoxy resin [48], silicone rubber [49, 50], UHMWPE [51], LDPE, HDPE, PP, PET [52], wood samples [53], etc.). The main characteristic absorption bands for fluorine-containing polymers and composites are presented in Table 1.

IR-spectroscopy also enables to perform in situ monitoring of fluorination process by means of IRtransparent beryllium window in the reactor's wall. So, gradual conversion of $-\mathrm{CH}_{2}-$ group of LDPE into - $\mathrm{CHF}-$ and $-\mathrm{CF}_{2}-$ was detected by shift of absorption band from 1,100 to $1,200 \mathrm{~cm}^{-1}[58,63]$.

\subsubsection{UV-Vis interferometry}

Interferometry in the ultraviolet-visible region (UV-Vis) has been applied for investigation of polymers since mid-to-late XXth century [64]. The technique is based on the analysis of the interference spectrum of the UV-visible light reflected from the layers in the sample at different depths. Kharitonov et al. suggested using the procedure for estimation of depth of fluorination [65]. In the case of thin layers, the thickness of the fluorinated layer is determined via interference of the UV-Vis light having passed through the sample and reflected twice from the

Table 1. Specific absorption bands for fluorine-containing polymers and composites

\begin{tabular}{lcc}
\hline \multicolumn{1}{c}{ Functional group } & Wavenumber, $\mathrm{cm}^{-1}$ & Reference \\
\hline $\mathrm{C}-\mathrm{F}$ (general) (str*) & 1,$200 ; 1,147 ; 554,509$ & {$[31,44,51,52,54-57]$} \\
$-\mathrm{CF}_{3}$ (str*) & $1,350-1,120$ & {$[44]$} \\
$-\mathrm{CF}_{2}-\left(\right.$ str* $\left.^{*}\right)$ & $1,280-1,120$ & {$[44,57]$} \\
$-\mathrm{CF}$ (aliphatic) (str*) & $1,100-1,000$ & {$[44,57,58]$} \\
$-\mathrm{CF}$ (aromatic) (str*) & $1,270-1,100$ & {$[44]$} \\
$-\mathrm{C}(\mathrm{O}) \mathrm{F}$ (str*) & $1,800-1,900$ & {$[55,59-61]$} \\
$\mathrm{Si}-\mathrm{F}$ (str*) & 850 & {$[62]$} \\
$*$ Stretch vibration. & & \\
\hline
\end{tabular}


fluorinated layer. This procedure can be realized when the fluorinated and non-fluorinated layers are separated by very thin boundary layer (not more than one fourth of light wavelength) and the boundary layer is parallel to the surface of the sample [34]. If the fluorinated polymer is not sufficiently transparent for UV-Vis light, the interference spectra can be measured in the reflection mode by changing the angle of incidence by $45^{\circ}$. The approach allows estimating fluorination depth from 0.1 to $50 \mu \mathrm{m}$ and performing in situ measurements of thickness of the fluorinated layer during the fluorination process [34]. It was applied for investigation of kinetics of fluorinated layer growth for various polymers: UHMWPE [66], HDPE [47, 67], PS [34], PET, PI, PPO, PVTMS [46, 68], PTFE [46], PEEK-WC [61], etc. Refractive indices $n_{V}^{D}$ for the conventional polymers vary in the range of $1.49-1.66$ while $n_{F}^{D}$ for the fluorinated layers of these polymers are within 1.35-1.41 (Table 2). The minimum difference between refractive indices of virgin and fluorinated layers for proper application of the technique should be higher than $0.03-0.05$.

The thickness of the fluorinated layer can be calculated based on the following equation:

$$
\delta_{F}=\frac{1}{2 n_{F}^{D} \Delta v}
$$

where $\Delta v\left(\mathrm{~cm}^{-1}\right)$ is an interval (a difference in wavenumbers) between neighboring maxima or minima in transmission spectra [65]. For most cases of gas-phase fluorination by elemental fluorine, the time dependence of the thickness as well as the total amount of fluorinated groups was shown to be proportional to the square root of fluorination time $t_{F}$ [66]. This fact proves that (i) the fluorinated polymeric film consists of fluorinated and virgin

Table 2. Refractive indices of virgin $\left(n_{V}^{D}\right)$ and fluorinated $\left(n_{F}^{D}\right)$ polymer layers estimated via $\mathrm{UV}-\mathrm{Vis}$ technique

\begin{tabular}{lcc}
\hline \multicolumn{1}{c}{ Polymer } & $n_{V}^{D}$ & $n_{F}^{D}$ \\
\hline PS [34] & 1.590 & 1.366 \\
PET [46,68] & 1.655 & 1.380 \\
Matrimid5218 [46, 68] & 1.63 & 1.41 \\
PPO [46, 68] & - & $1.373-1.381$ \\
PVTMS [46, 68] & 1.492 & 1.376 \\
\hline
\end{tabular}

layers separated by very thin $(<<0.1 \mu \mathrm{m})$ boundary where the most chemical reactions take place and (ii) the rate of generation of fluorinated layer results from diffusion of fluorine through the modified layer to the untreated one.

\subsubsection{NMR-spectroscopy}

Nuclear magnetic resonance is a routine tool of investigation of chemical structure of polymers. The elements having magnetic momentum (for instance, ${ }^{1} \mathrm{H},{ }^{3} \mathrm{H},{ }^{13} \mathrm{C},{ }^{15} \mathrm{~N},{ }^{19} \mathrm{~F},{ }^{29} \mathrm{Si},{ }^{31} \mathrm{P}$ and others) can be tested by NMR technique. Each atom possesses a unique chemical shift relatively to a standard, depending on electronic structure of a nucleus, atoms bonded with this atom, spatial environment, etc. Exhaustive data on the chemical structure of a polymer can be obtained on the basis of chemical shift and spin-spin coupling parameters [69-72]. A wide range of procedures of NMR are currently available but among them NMR of samples in deuterated solvents and magic angle spinning NMR (MAS NMR) are most spread. The former approach has a drawback associated with a weak solubility of fluorinated polymers in most of the solvents. While the latter (MAS NMR) allows measuring of NMR spectra of solid samples that has promoted a wide application of this technique in analysis of fluorinated polymers. Trichlorofluoromethane is often chosen as internal standard while 1,1,2-trichloro-1,2,2-trifluoroethane $\left(\delta\left({ }^{19} \mathrm{~F}\right)=-68.05\right.$, $-72.20 \mathrm{ppm})$, trifluoroacetic acid $\left(\delta\left({ }^{19} \mathrm{~F}\right)=-78.4 \mathrm{ppm}\right)$, C6F6 $\left(\delta\left({ }^{19} \mathrm{~F}\right)=-163 \mathrm{ppm}\right)$, sodium trifluoromethane sulfonate $\left(\delta\left({ }^{19} \mathrm{~F}\right)=-80.8 \mathrm{ppm}\right)$, PTFE $\left(\delta\left({ }^{19} \mathrm{~F}\right)=\right.$ $=-122 \mathrm{ppm})$ and others $[53,57,66,73-76]$ are used as external standards for correction of chemical shifts of fluorine nuclei. The NMR is a sufficiently sensitive method and enables an estimation of the fluorination degree for the fluorinated polymers via ratio of signals from different functional groups (Table 3). It also allows calculating average molecular mass of a polymer by the ratio of side functional groups to the amount of polymer units according to the corresponding chemical shifts of atom nuclei [53, 57, 58, 66, 77-81]. An example of the NMR analysis of highly fluorinated polymer is provided for long-term liquid-phase fluorination of poly(2,6-dimethylphenylene oxide-1,4) powder in pefluorodecalin (PFD) [82]. The product of the fluorination was soluble in PFD and perfluorobenzene, and was shown by standard ${ }^{19} \mathrm{~F}$, ${ }^{13} \mathrm{C}$ NMR approaches to have structure of poly(perfluorocyclohexenyl ether) [82]. 
Table 3. Specific chemical shifts of ${ }^{19} \mathrm{~F}$ and ${ }^{13} \mathrm{C}$ in various functional groups

\begin{tabular}{lccc}
\hline Functional group & Chemical shift of ${ }^{19} \mathrm{~F}, \mathrm{ppm}$ & Chemical shift of ${ }^{13} \mathrm{C}, \mathrm{ppm}$ & References \\
\hline $\mathrm{CF}$ & $-144,-138,-200$ & $100-103$ & {$[66,75,76,79]$} \\
$\mathrm{CF}_{2}$ & -122 & 107.8 & {$[53,66,75,76,79]$} \\
$\mathrm{CF}_{3}$ & -80 & 118.3 & {$[75,76]$} \\
$\mathrm{SCF}_{2}$ & $-114,-118$ & 112 & {$[75,76,83]$} \\
$\mathrm{OCF}_{2}$ & $-78,-80,-85$ & 116.8 & {$[83]$} \\
$\mathrm{CF}_{2} \mathrm{SO}_{2} \mathrm{~F}$ & $44-45$ (from $\mathrm{SO}_{2} \mathrm{~F}$ group) & $112-114$ & \\
\hline
\end{tabular}

\subsubsection{X-ray photoelectron spectroscopy (XPS)}

$\mathrm{X}$-ray photoelectron spectroscopy is a high demand technique to investigate chemical composition of polymeric surface [42, 84, 85]. The method is based on photoelectron effect when electrons are emitted from the sample due to its exposition to mild X-ray radiation of specific energy $(\mathrm{Mg}$ or $\mathrm{Al} \mathrm{K} \alpha$ radiation source with $2-20 \mathrm{keV})$. Analysis of the amount and energy of the photoelectrons allows estimating the content of elements (except hydrogen) and nature of their bonds since the binding energy of the electron with nucleus (i) has unique characteristic value for each element and (ii) depends on the electron environment of the element and can be shifted if it is bound to an element having different electronegativity (Table 4) $[42,86]$. The signal of aliphatic carbon in the chemical group $-\mathrm{CH}_{2}-$ with energy as high as $284.5-285.0 \mathrm{eV}$ is often utilized as internal standard. The XPS technique also allows investigating the sample surface within the thickness up to 5-7 $\mathrm{nm}$ [86]. The depth of the layer analyzed also results from the angle of incidence of X-ray beam. So, the fluorine atom $\left(\mathrm{F}_{1 \mathrm{~s}}, 686-689 \mathrm{eV}\right)$ can be detected on the depths of ca. $0.8 \mathrm{~nm}\left(\right.$ at $\left.80^{\circ}\right), 3.4 \mathrm{~nm}\left(\right.$ at $\left.45^{\circ}\right)$ and $4.8 \mathrm{~nm}\left(\right.$ at $\left.0^{\circ}\right)$ in the case of non-monochromatic anode radiation $\mathrm{Mg} \mathrm{K \alpha}$, and on the depths of ca. $1.1 \mathrm{~nm}\left(\right.$ at $80^{\circ}$ ), $4.5 \mathrm{~nm}\left(\right.$ at $\left.45^{\circ}\right)$ and $6.3 \mathrm{~nm}\left(\right.$ at $\left.0^{\circ}\right)$ in the case of monochromatic anode radiation $\mathrm{Mg} \mathrm{K \alpha}[86,87]$. XPS approach has high sensitivity (ca. $0.1 \%$ ) and good spatial resolution (ca. 2-5 $\mu \mathrm{m}$ ) that enables element and its bonds mapping over the surface and depth of the sample [42, 84-90]. XPS was effectively applied in the series of investigations by Cheng et al. [54, 91, 92], Nazarov et al. [35, 52, 93], and other researchers [67, 81, 94-96].

Table 4. The specific binding energies of electron in carbon and fluorine atoms of F-containing functional groups

\begin{tabular}{ll}
\hline \multicolumn{1}{c}{ Functional piece } & \multicolumn{1}{c}{ Chemical shift, eV } \\
\hline$\left(-\mathrm{CHF}-\mathrm{CH}_{2}-\right)_{n}$ & $\mathrm{C}_{1 \mathrm{~s}}: 287.91[97,98], 288[99](\mathrm{CF}) ; 285.7[97,99]\left(\mathrm{CH}_{2}\right)$ \\
& $\mathrm{F}_{1 \mathrm{~s}}: 686.94[97], 689.3[99](\mathrm{F})$ \\
$\left(-\mathrm{CF}_{2}-\mathrm{CH}_{2}-\right)_{n}$ & $\mathrm{C}_{1 \mathrm{~s}}: 290.9[97-99]\left(\mathrm{CF}_{2}\right) ; 286.44[97], 286.3[99]\left(\mathrm{CH}_{2}\right)$ \\
& $\mathrm{F}_{1 \mathrm{~s}}: 688.15[97] ; 689.6[99](\mathrm{F})$ \\
$\left(-\mathrm{CF}_{2}-\mathrm{CF}_{2}-\right)_{n}$ & $\mathrm{C}_{1 \mathrm{~s}}: 292.48[85,97-99]\left(\mathrm{CF}_{2}\right)$ \\
& $\mathrm{F}_{1 \mathrm{~s}}: 689.67[97], 690.2[99], 689.7[85](\mathrm{F})$ \\
$(-\mathrm{CFH}-\mathrm{CFH}-)_{n}$ & $\mathrm{C}_{1 \mathrm{~s}}: 288.4[99,100](\mathrm{CF})$ \\
& $\mathrm{F}_{1 \mathrm{~s}}: 689.3(\mathrm{~F})[100]$ \\
$\left(-\mathrm{CF}{ }_{2}-\mathrm{CFH}-\right)_{n}$ & $\mathrm{C}_{1 \mathrm{~s}}: 291.6\left(\mathrm{CF}_{2}\right) ; 289.3(\mathrm{CFH})[97,98]$ \\
& $\mathrm{F}_{1 \mathrm{~s}}: 690.1(\mathrm{~F})[97]$ \\
$\mathrm{CF}_{3}-\mathrm{CH}-\mathrm{O}-$ & $\mathrm{C}_{1 \mathrm{~s}}: 292.2\left(\mathrm{CF}_{3}\right)[98]$ \\
$\mathrm{CF}_{3}-\mathrm{CF}_{2}-($ perfluorinated polymers $)$ & $\mathrm{C}_{1 \mathrm{~s}}: 295.6\left(\mathrm{CF}_{3}\right), 291.3\left(\mathrm{CF}_{2}\right)[98]$ \\
$\left(-\mathrm{CH}_{2} \mathrm{CH}\left(\mathrm{OC}(\mathrm{O}) \mathrm{CF}_{3}\right)-\right)_{n}$ & $\mathrm{C}_{1 \mathrm{~s}}: 292.65\left(\mathrm{CF}_{3}\right)[97]$ \\
& $\mathrm{F}_{1 \mathrm{~s}}: 688.15(\mathrm{~F})[97]$ \\
\hline
\end{tabular}




\subsection{Microscopic methods}

The AFM technique is based on monitoring of the polymeric surface by a cantilever, and detection of energy of its interaction with the surface. The method possesses high resolution along the thickness and the width of the surface that enables to perform 2D and 3D morphological analysis of the polymeric layers. Hardness, electroconductivity, adhesive and magnetic properties, roughness can be estimated in a pointwise manner. The analysis can be performed in various media (vacuum, air, inert gases, liquids) allowing to study influence of media composition on surface properties of polymer [42]. The technique was applied in investigation of surface morphology of polymers and composite materials after fluorination elsewhere [52, 101-103].

Scanning electron microscopy (SEM) is a widely applicable technique to test a surface of polymeric samples. The method is based on scanning of sample surface by a focused primary electron beam resulting in emission of secondary electrons. The intensity of secondary electrons depends on atomic number of the element: the higher the number is the larger intensity of the electrons becomes. The method allows testing the topology, morphology and crystallographic nature of the samples [104]. For instance, for the majority of polymers (UHMWPE, LDPE, PPTA, PET, PP, fir wood, etc.), an increase in roughness was observed $[53,52,96]$. By means of this technique, An et al. estimated nanoparticle size distribution and roughness of the surface of high temperature vulcanized composites made of silicone rubber and nanosilica [50].

It is worth noting that SEM has been applied for estimation of depth of fluorination by preparation and analysis of cross-section of the polymeric films $[48,50,105,106]$. Moreover, SEM is often combined with energy dispersive X-ray spectroscopy (EDXS). During the measurement, spectra of energy of X-ray emission after exposure of the sample to electron or $\mathrm{X}$-ray beam are recorded. Each atom has a unique configuration of electrons and, hence, has a specific spectrum of X-ray emission. Thus, the SEM-EDXS coupling allows one to perform quantitative and qualitative elemental analysis (hydrogen excluded) of polymeric surface $[107,108]$. Wirti et al. showed that surface concentration of C-F bonds achieved $2.5 \%$ after treatment of Kevlar fibers by hydrofluoric acid [109]. A uniformity of the surface fluorination of polymers was also demonstrated elsewhere [31, 48, $51,59,95,110]$.

\subsection{Other techniques for analysis of structure of fluorine-containing polymers}

The secondary ion mass spectrometry became widely used in polymer testing in the late twentieth century [111-114]. The method is based on bombardment of polymer surface by primary ions (for instance, $\mathrm{Xe}^{+}, \mathrm{Cs}^{+}, \mathrm{Ga}^{+}$) resulting in ionization and desorption of monoatomic layers (formation of secondary ions) that allows carrying out analysis of elemental and molecular composition within thickness as large as $5 \AA$ [86]. So, time-of-flight procedure of SIMS has detected the following molecular ions in the chemical structure of fluorinated polymers: $\mathrm{CF}_{3}-, \mathrm{C}_{2} \mathrm{~F}_{5}^{-}, \mathrm{C}_{3} \mathrm{~F}_{7}^{-}, \mathrm{CHF}_{2}$, $\mathrm{CHOF}_{4}{ }^{-}, \mathrm{CH}_{2} \mathrm{OF}_{5}{ }^{-}, \mathrm{SiF}, \mathrm{C}_{7} \mathrm{H}_{2} \mathrm{~F}_{5}{ }^{+}, \mathrm{C}_{8} \mathrm{H}_{2} \mathrm{~F}_{5}{ }^{+}, \mathrm{C}_{8} \mathrm{H}_{4} \mathrm{~F}_{5}{ }^{+}$, $\mathrm{C}_{9} \mathrm{H}_{4} \mathrm{~F}_{5}{ }^{+}, \mathrm{C}_{15} \mathrm{H}_{3} \mathrm{~F}_{10}$, etc [115-118]. In addition, the SIMS technique is often used for estimation of depth of fluorination, its uniformity [119-120] and distribution of fluorine-containing additives over the sample [115, 121, 122].

Oppositely, electron paramagnetic resonance (EPR) can be considered as a non-destructive method for detection of paramagnetic species (point defects, free radical, biradicals, transition metal ions, etc.) $[123,124]$. For the polymers after contact with elemental fluorine, the presence of long-lived radicals was proved by EPR technique [63, 125, 126]. Peyroux et al. showed that during fluorination of LDPE the following radical structures formation took place: $-\mathrm{CF}_{2}-\mathrm{C}^{*} \mathrm{~F}-\mathrm{CFH}-$ and $-\mathrm{CF}_{2}-\mathrm{C}^{*} \mathrm{H}-\mathrm{CF}_{2}-$. Their intensities decreased after the exposure to air due to attack of oxygen resulting in the formation of peroxide radicals and subsequent oxidation $[58,63$, $102,125]$.

A combination of the aforementioned chemical, spectroscopic, spectrometric and other techniques for estimation of chemical structure and morphology of the fluorinated materials (polymers, layers) expands the insight into the interaction of the polymers with elemental fluorine comprehensively.

\section{Results and Discussion}

The range of techniques, which can be applied for the characterization and structure evaluation of fluorinated polymers, highlight the complex character of surface fluorination and necessity to use various chemical and physical approaches for the study. The fluorination of surface layers determines the apparent changes in the chemical composition, morphology, spectroscopic properties and surface features. Thus, the full characterization of polymers should be provided especially in case of polymers for 
the specific applications. UV-Vis spectroscopy is excellent for in situ control of thickness of the fluorinated layers and provided the general information about optic properties. The chemical and morphological analysis of cross-section and surface of the fluorinated layers can be conducted using XPS, AFM, SEM, SIMS approaches. Finally, chemical analysis can be performed by flask combustion method, CHNSO analysis, NMR, XPS, SIMS.

\section{Funding}

This research was funded by Ministry of Science and Higher Education of Russian Federation, project FSWW-2020-0020.

\section{Conflict of interests}

The authors declare no conflict of interest.

\section{References}

1. Ameduri BM. Fluoropolymers: the right material for the right applications. Chemistry-A European Journal. 2018;24(71):18830-18841. DOI:10.1002/chem.201802708

2. Dams R, Hintzer K. Fluorinated Polymers: Vol. 2: Applications. Cambridge: Royal Society of Chemistry; 2017;24:1-31.

3. Yao W, Li Y, Huang X. Fluorinated poly(meth) acrylate: synthesis and properties. Polymer. 2014;24(55): 6197-6211. DOI:10.1016/j.polymer.2014.09.036

4. Imae T. Fluorinated polymers. Current Opinion in Colloid \& Interface Science. 2003;8(3):307-314. DOI:10.1016/S1359-0294(03)00050-5

5. Do K, Saleem Q, Ravva MK, Cruciani F, Kan Z, Wolf J, Hansen MR, Beaujuge PM, Bredas J-L. Impact of fluorine substituents on $\pi$-conjugated polymer main-chain conformations, packing, and electronic couplings. Advanced Materials. 2016;28(37):8197-8205. DOI: 10.1002/adma.201601282

6. Zhao X-Y, Liu H-J. Review of polymer materials with low dielectric constant. Polymer International. 2010;59(5):597-606. DOI:10.1002/pi.2809

7. Awang $\mathrm{N}$, Ismail AF, Jaafar J, Matsuura $\mathrm{T}$, Junoh H, Othman MHD, Rahman MA. Functionalization of polymeric materials as a high performance membrane for direct methanol fuel cell: a review. Reactive and Functional Polymers. 2015;86:248-258. DOI:10.1016/ j.reactfunctpolym.2014.09.019

8. Zhou H, Yang L, Stuart AC, Price SC, Liu S, You W. Development of fluorinated benzothiadiazole as a structural unit for a polymer solar cell of $7 \%$ efficiency. Angewandte Chemie. 2011;50(13):2995-2998. DOI:10.1002/anie.201005451

9. Sun H, Tang Y, Koh CW, Ling S, Wang R, Yang K, Yu J, Shi Y, Wang Y, Woo HY, Guo X. High-performance all-polymer solar cells enabled by an $n$-type polymer based on a fluorinated imidefunctionalized arene. Advanced Materials. 2019;31(15):1807220(1-8). DOI:10.1002/adma.201807220
10. Chen S, An Y, Dutta GK, Kim Y, Zhang Z-G, Li Y, Yang C. A synergetic effect of molecular weight and fluorine in all-polymer solar cells with enhanced performance. Advanced Functional Materials. 2016;27(2):1603564(1-10). DOI:10.1002/adfm.201603564

11. Quartarone E, Angioni S, Mustarelli P. Polymer and composite membranes for proton-conducting, hightemperature fuel cells: a critical review. Materials. 2017;10(7):687(1-17). DOI:10.3390/ma10070687

12. Zhang Q, Kelly MA, Bauer N, You W. The curious case of fluorination of conjugated polymers for solar cells. Accounts of Chemical Research. 2017;50(9):2401-2409. DOI:10.1021/acs.accounts.7b00326

13. Tumbleston JR, Stuart AC, Gann E, You W, Ade H. Fluorinated polymer yields high organic solar cell performance for a wide range of morphologies. Advanced Functional Materials. 2013;23(27):3463-3470. DOI:10.1002/adfm.201300093

14. Cardoso VF, Correia DM, Ribeiro C, Fernandes MM, Lanceros-Mendez S. Fluorinated polymers as smart materials for advanced biomedical applications. Polymers. 2018;10(2):161(1-26). DOI:10.3390/ polym10020161

15. Tathe A, Ghodke M, Nikalje AP. Brief review: biomaterials and their application. International Journal of Pharmacy and Pharmaceutical Sciences. 2010;2(4):19-23.

16. Sanders DF, Smith ZP, Guo R, Robeson LM, McGrath JE, Paul DR, Freeman BD. Energy-efficient polymeric gas separation membranes for a sustainable future: a review. Polymer. 2013;54(18):4729-4761. DOI:10.1016/j.polymer.2013.05.075

17. Ivanchev SS, Myakin SV. Polymer membranes for fuel cells: manufacture, structure, modification, properties. Russian Chemical Reviews. 2010;79(2):101-117. DOI:10.1070/RC2010v079n02ABEH004070

18. Ahmad NA, Leo CP, Ahmad AL, Ramli WKW. Membranes with great hydrophobicity: a review on preparation and characterization. Separation \& Purification Reviews. 2013;44(2):109-134. DOI:10.1080/ 15422119.2013.848816

19. Peighambardoust SJ, Rowshanzamir S, Amjadi M. Review of the proton exchange membranes for fuel cell applications. International Journal of Hydrogen Energy. 2010;35(17):9349-9384. DOI:10.1016/j.ijhydene.2010.05.017

20. Kim DJ, Jo MJ, Nam SY. A review of polymernanocomposite electrolyte membranes for fuel cell application. Journal of Industrial and Engineering Chemistry. 2015;21(25):36-52. DOI:10.1016/j.jiec.2014.04.030

21. Okamoto Y, Du Q, Koike K, Mikes F, Merkel TC, He Z, Zhang H, Koike Y. New amorphous perfluoro polymers: perfluorodioxolane polymers for use as plastic optical fibers and gas separation membranes. Polymers for Advanced Technologies. 2015;27(1):33-41. DOI:10.1002/ pat. 3600

22. Li Q, Yan Y, Yu M, Song B, Shi S, Gong Y. Synthesis of polymeric fluorinated sol-gel precursor for fabrication of superhydrophobic coating. Applied Surface Science. 2016;367:101-108. DOI:10.1016/j.apsusc.2016.01.155 
23. Hetemi D, Pinson J. Surface functionalisation of polymers. Chemical Society Reviews. 2017;46:5701-5713. DOI:10.1039/C7CS00150A

24. Xue Z, Liu M, Jiang L. Recent developments in polymeric superoleophobic surfaces. Journal of Polymer Science, Part B: Polymer Physics. 2012;50(17):1209-1224. DOI:10.1002/polb.23115

25. Simpson JT, Hunter SR, Aytug T. Superhydrophobic materials and coatings: a review. Reports on Progress in Physics. 2015;78(8):086501(1-14). DOI:10.1088/0034-4885/78/8/086501

26. Pagliaroa M, Ciriminna R. New fluorinated functional materials. Journal of Materials Chemistry. 2005;15:4981-4991. DOI:10.1039/B507583C

27. Schöniger W. Eine mikroanalytische schnellbestimmung von halogen in organischen substanzen. Microchimica Acta. 1995;43(1):123-129. DOI:10.1007/BF01220660

28. Maity J, Jacob C, Das CK, Kharitonov AP, Singh RP, Alam S. Fluorinated aramid fiber reinforced polypropylene composites and their characterization. Polymer Composites. 2007;28(4):462-469. DOI: 10.1002/pc.20303.

29. Maity J, Jacob C, Singh RP. Effect of surface fluorination of poly (p-phenylene terephthalamide) fiber. Defence Science Journal. 2014;64(3):230-235. DOI: $10.14429 /$ dsj.64.7321

30. Hruska Z, Lepot X. Surface modification of polymer webs by oxyfluorination. Journal of Plastic Film \& Sheeting. 1999;15(3):235-255. DOI:10.1177/ 875608799901500306

31. Fan C, Li B, Ren M, Wu P, Liu Y, Chen T, Cheng Z, Qin J, Liu X. The reaction kinetics and mechanism of crude fluoroelastomer vulcanized by direct fluorination with fluorine/nitrogen gas. RSC Advances. 2015;5(24):18932-18938. DOI:10.1039/C4RA15096A

32. Geng W, Furuzono T, Nakajima T, Takanashi H, Ohki A. Determination of total arsenic in coal and wood using oxygen flask combustion method followed by hydride generation atomic absorption spectrometry. Journal of Hazardous Materials. 2010;176(1-3):356-360. DOI:10.1016/j.jhazmat.2009.11.035

33. Mukherjee M, Das CK, Kharitonov AP, Banik K, Mennig G, Chung TN. Properties of syndiotactic polystyrene composites with surface modified short Kevlar fiber. Materials Science and Engineering. 2006;441(1-2): 206-214. DOI:10.1016/j.msea.2006.08.004

34. Kharitonov AP, Moskvin YL. Direct fluorination of polystyrene films. Journal of Fluorine Chemistry. 1998;91(1):87-93. DOI:10.1016/S0022-1139(98)00200-0

35. Nazarov VG. Structure and composition of the surface layer in polymers modified by elemental fluorine. Journal of Applied Polymer Science. 2005;95(4):897-902. DOI:10.1002/app.21292

36. Gao J, Wang X, Wei Y, Yang W. Synthesis and characterization of a novel fluorine-containing polymer emulsion with core/shell structure. Journal of Fluorine Chemistry. 2006;127(2):282-286. DOI:10.1016/j.jfluchem. 2005.12.002
37. Wei H, Wang F, Qian X, Li S, Hu Z, Sun H, Zhu Z, Liang W, Ma C, Li A. Superhydrophobic fluorinerich conjugated microporous polymers monolithic nanofoam with excellent heat insulation property. Chemical Engineering Journal. 2018;351(1):856-866. DOI:10.1016/j.cej.2018.06.162

38. Zhang D, Xing P, Pan R, Lin X, Sha M, Jiang B. Preparation and surface properties study of novel fluorinecontaining methacrylate polymers for coating. Materials. 2018;11:2258. DOI:10.3390/ma11112258

39. Singh A, Singh S, Sharma TC, Kishore P. Physicochemical properties and kinetic analysis for some fluoropolymers by differential scanning calorimetry. Polymer Bulletin. 2017;75(6):2315-2338. DOI:10.1007/ s00289-017-2153-5

40. Pasquini C. Near infrared spectroscopy: a mature analytical technique with new perspectives - a review. Analytica Chimica Acta. 2018;1026:8-36. DOI:10.1016/ j.aca.2018.04.004

41. Bhargava R, Wang SQ, Koenig JL. Liquid Chromatography/FTIR Microspectroscopy/Microwave Assisted Synthesis. Berlin: Springer; 2003. 191 p.

42. Stamm M. Polymer surfaces and interfaces. Characterization, Modification and Applications. Berlin: Springer; 2008. 47-70 p.

43. De los Santos-Villarreal G, Elizalde LE, Handbook of Polymer Synthesis, Characterization, and Processing. New York: John Wiley \& Sons Inc.; 2013. 335-354 p.

44. Larkin P. Infrared and Raman spectroscopy: principles and spectral interpretation. Oxford: Elsevier; 2018. 29-61 p.

45. Griffiths PR, De Haseth JA. Fourier transform infrared spectrometry. New York: John Wiley \& Sons Inc.; $2007.535 \mathrm{p}$.

46. Kharitonov AP, Loginov BA. Direct fluorination of polymer final products: from fundamental study to practical application. Russian Journal of General Chemistry. 2009;79(3):635-641. DOI:10.1134/S1070363209030451

47. Tressaud A, Durand E, Labrugčre C, Kharitonov AP, Simbirtseva GV, Kharitonova LN, Dubois M. Surface modification of polymers treated by various fluorinating media. Acta Chimica Slovenica. 2013;60(3):495-504.

48. An Z, Xiao H, Liu F, Zheng F, Lei Q, Zhang Y. Improved resistance of epoxy resin to corona discharge by direct fluorination. IEEE Transactions on Dielectrics and Electrical Insulation. 2016;23(4):2278-2287. DOI:10.1109/ TDEI.2016.7556504

49. Du B, Li Z, Li J. Surface charge accumulation and decay of direct-fluorinated RTV silicone rubber. IEEE Transactions on Dielectrics and Electrical Insulation. 2014;21(5):2338-2342. DOI:10.1109/TDEI.2014.004079

50. An Z, Gu X, Shen R, Tang Y, Zheng F, Zhang Y, Yang L. Resistance to corona discharge of HTV silicone rubber surface layers fluorinated at different temperatures. IEEE Transactions on Dielectrics and Electrical Insulation. 2018;25(2):729-740. DOI:10.1109/TDEI.2018.006992

51. Nazarov VG, Nagornova IV, Stolyarov VP, Doronin FA, Evdokimov AG, Brevnov PN, Zabolotnov AS, 
Novokshonova LA. Effect of fluorination of ultrahighmolecular-weight polyethylene. Russian Journal of Physical Chemistry. 2018;12(6):1066-1075. DOI:10.1134/ S1990793118060088

52. Nazarov VG, Doronin FA, Evdokimov AG, Rytikov GO, Stolyarov VP. Oxyfluorination-controlled variations in the wettability of polymer film surfaces. Colloid Journal. 2019;81(2):146-157. DOI:10.1134/ S1061933X1902011X

53. Pouzet M, Dubois M, Charlet K, Béakou A, Leban JM, Baba M. Fluorination renders the wood surface hydrophobic without any loss of physical and mechanical properties. Industrial Crops and Products. 2019;133:133-141. DOI:10.1016/j.indcrop.2019.02.044

54. Cheng Z, Li B, Huang J, Chen T, Liu Y, Wang X, Liu X. Covalent modification of aramid fibers' surface via direct fluorination to enhance composite interfacial properties. Materials \& Design. 2016;106:216-225. DOI:10.1016/j.matdes.2016.05.120

55. Li B, Li M, Fan C, Ren M, Wu P, Luo L, Wang X, Liu X. The wear-resistance of composite depending on the interfacial interaction between thermoplastic polyurethane and fluorinated UHMWPE particles with or without oxygen. Composites Science and Technology. 2015;106:68-75. DOI:10.1016/j.compscitech.2014.11.005

56. Liu Y, Chen Q, Du X, Li L, Li P. Surface modification of polyethylene terephthalate films by direct fluorination. AIP Advances. 2018;8(12):125333. DOI:10.1063/1.5066246.

57. Pouzet M, Dubois M, Charlet K, Beakou A. From hydrophilic to hydrophobic wood using direct fluorination: a localized treatment. Comptes Rendus Chimie. 2018;21(8):800-807. DOI:10.1016/j.crci.2018.03.009

58. Peyroux J, Dubois M, Tomasella E, Frézet L, Kharitonov AP, Flahaut D. Enhancement of surface properties on low density polyethylene packaging films using various fluorination routes. European Polymer Journal. 2015;66:18-32. DOI:10.1016/j.eurpolymj. 2014.12.040

59. Du BX, Li ZL, Li J. Effects of direct fluorination on space charge accumulation in HTV silicone rubber. IEEE Transactions on Dielectrics and Electrical Insulation. 2016;23(4):2353-2360. DOI:10.1109/ TDEI.2016.7556513

60. Kharitonov AP. Direct fluorination of polymers from fundamental research to industrial applications. Progress in Organic Coatings. 2008;61(2-4):192-204. DOI:10.1016/j.porgcoat.2007.09.027

61. De Luca G, Kharitonov A, Tocci E, Drioli E. Experimental and computational study on direct fluorination of PEEKWC membranes. Separation and Purification Technology. 2019;227:115676(1-11). DOI:10.1016/j.seppur.2019.115676

62. Shimada T, Katayama Y, Horigome S. Infrared spectra of amorphous silicon-fluorine alloys prepared by sputtering in fluorosilane-argon gas mixture. Japanese Journal of Applied Physics. 1980;19(5):L265. DOI: 10.1143/JJAP.19.L265

63. Peyroux J, Dubois M, Tomasella E, Batisse N, Kharitonov AP, Flahaut D, Romana L, Thomas P. Surface modification of low-density polyethylene packaging film via direct fluorination. Surface and Coatings Technology. 2016;292:144-154. DOI:10.1016/j.surfcoat.2016.03.021

64. Seymour R, Carraher C. Polymer Chemistry: An Introduction. New York: Plenum; 1981. 576 p.

65. Kharitonov AP, Moskvin YL, Kolpakov GA. Application of interference spectroscopy for studying kinetics of chemical reactions in optically transparent films. Polymer Science USSR. 1985;27(3):739-743. DOI: 10.1016/0032-3950(85)90261-8

66. Kharitonov AP, Simbirtseva GV, Bouznik VM, Chepezubov MG, Dubois M, Guérin K, Hamwi A, Kharbache H, Masin F. Modification of ultra-highmolecular weight polyethylene by various fluorinating routes. Journal of Polymer Science Part A: Polymer Chemistry. 2011;49(16):3559-3573. DOI:10.1002/pola.24793

67. Kharitonov AP, Simbirtseva GV, Tressaud A, Durand $E$, Labrugère $C$, Dubois $M$. Comparison of the surface modifications of polymers induced by direct fluorination and rf-plasma using fluorinated gases. Journal of Fluorine Chemistry. 2014;165:49-60. DOI:10.1016/ j.jfluchem.2014.05.002

68. Kharitonov AP, Kharitonova LN. Surface modification of polymers by direct fluorination: a convenient approach to improve commercial properties of polymeric articles. Pure and Applied Chemistry. 2009;81(3):451-471. DOI:10.1351/PAC-CON-08-06-02

69. Adams A. Analysis of solid technical polymers by compact NMR. TrAC Trends in Analytical Chemistry. 2016;83:107-119. DOI:10.1016/j.trac.2016.04.003

70. Tanaka S, Liao WC, Ogaw A, Sato K, Copéret C. DNP NMR spectroscopy of cross-linked organic polymers: rational guidelines towards optimal sample preparation. Physical Chemistry Chemical Physics. 2020;22(6):31843190. DOI:10.1039/c9cp05208a

71. Hansen MR, Graf R, Spiess HW. Interplay of structure and dynamics in functional macromolecular and supramolecular systems as revealed by magnetic resonance spectroscopy. Chemical Reviews. 2016;116(3):1272-1308. DOI:10.1021/acs.chemrev.5b00258

72. Kaźmierski S, Pawlak $\mathrm{T}$, Jeziorna A, Potrzebowski MJ. Modern solid state NMR techniques and concepts in structural studies of synthetic polymers. Polymers for Advanced Technologies. 2016;27(9):1143-1155. DOI:10.1002/pat.3780

73. Takasaki M, Kimura K, Kawaguchi K, Abe A, Katagiri G. Structural Analysis of a perfluorosulfonate Ionomer in solution by ${ }^{19} \mathrm{~F}$ and ${ }^{13} \mathrm{C}$ NMR. Macromolecules. 2005;38(14):6031-6037. DOI:10.1021/ma047970h

74. Petit F, Iliopoulos I, Audebert R. Aggregation of associating polymers studied by ${ }^{19} \mathrm{~F}$ NMR. Polymer. 1998;39(3):751-753. DOI:10.1016/S0032-3861(97)00429-1

75. Yan ZB, Hayes R, Melo LG, Goward GR, Hitchcock AP. X-ray absorption and solid-state NMR spectroscopy of fluorinated proton conducting polymers. The Journal of Physical Chemistry C. 2018;122(6):32333244. DOI:10.1021/acs.jpcc.7b11592

76. Chen Q, Schmidt-Rohr K. ${ }^{19} \mathrm{~F}$ and ${ }^{13} \mathrm{C}$ NMR signal assignment and analysis in a perfluorinated ionomer (Nafion) by two-dimensional solid-state NMR. 
Macromolecules. 2004;37(16):5995-6003. DOI:10.1021/ ma049759b

77. Peyroux J, Dubois M, Tomasella E, Petit E, Flahaut D. Enhancement of surface properties on commercial polymer packaging films using various surface treatment processes (fluorination and plasma). Applied Surface Science. 2014;315:426-431. DOI:10.1016/j.apsusc. 2014.05.163

78. Pouzet M, Gautier D, Charlet K, Dubois M, Beakou A. How to decrease the hydrophilicity of wood flour to process efficient composite materials. Applied Surface Science. 2015;353:1234-1241. DOI:10.1016/ j.apsusc.2015.06.100

79. Pouzet M, Dubois M, Charlet K, Petit E, Beakou A, Dupont C. Fluorination/Torrefaction combination to further improve the hydrophobicity of wood. Macromolecular Chemistry and Physics. 2019;220(14):1900041(1-5). DOI:10.1002/macp.201900041

80. Saulnier F, Dubois M, Charlet K, Frezet L, Beakou A. Direct fluorination applied to wood flour used as a reinforcement for polymers. Carbohydrate Polymers. 2013;94(1):642-646. DOI:10.1016/j.carbpol.2013.01.060

81. Zha J, Ali SS, Peyroux J, Batisse N, Claves D, Dubois M, Kharitonov AP, Monier G, Darmanin T, Guittard F, Alekseiko LN. Superhydrophobicity of polymer films via fluorine atoms covalent attachment and surface nano-texturing. Journal of Fluorine Chemistry. 2017;200:123-132. DOI:10.1016/j.jfluchem.2017.06.011

82. Blinov IA, Mukhortov DA, Yampolskii YP, Belov NA, Alentiev AY, Chirkov SV, Bondarenko GN, Kostina YV, Legkov SA, Perepuchov AM, Kambur MP, Kambur PS, Kapustin VV, Vozniuk ON, Kurapova ES. Direct fluorination of poly-2,6-dimethyl-1,4-phenylene oxide in perfluorinated liquid medium. Journal of Fluorine Chemistry. 2020;234:109526(1-10). DOI:10.1016/ j.jfluchem.2020.109526

83. Hamel NN. Monomeric and Polymeric Fluoroalkyl Sulfonyl Fluorides, Sulfonate Salts and Sulfonic Acids for Use as Electrolytes and Coatings. $\mathrm{PhD}$ Thesis, Portland, 1995. 163 p. DOI:10.15760/etd.1264

84. Chan C-M. Polymer surface modification and characterization. Munich: Hanser Publisher; 1993. 285 p.

85. Beamson G, Briggs D. High resolution XPS of organic polymers: The Scienta ESCA 300 database. Chichester: John Wiley \& Sons; 1992. 295 p.

86. Van de Grampel RD. Surfaces of fluorinated polymer systems. PhD Thesis, Eindhoven, 2002. 151 p.

87. Zhuang $\mathrm{H}$, Marra KG, Ho T, Chapman TM, Gardella JA. Surface composition of fluorinated poly (amide urethane) block copolymers by electron spectroscopy for chemical analysis. Macromolecules. 1996;29(5):1660-1665. DOI:10.1021/ma950860d

88. Chan CM, Weng LT. Surface characterization of polymer blends by XPS and ToF-SIMS. Materials. 2016;9(8):655. DOI:10.3390/ma9080655

89. Briggs D. Surface analysis of polymers by XPS and static SIMS. Cambridge: Cambridge University Press; 1998. $214 \mathrm{p}$.
90. Tsibouklis J, Stone M, Thorpe AA, Graham P, Nevell TG, Ewen RJ. Surface energy characteristics of polymer film structures: a further insight into the molecular design requirements. Langmuir. 1999;15(20):7076-7079. DOI:10.1021/la990411x

91. Cheng Z, Wu P, Gao J, Wang X, Ren M, Li B, Luo L, Liu X. Structural evolution of fluorinated aramid fibers with fluorination degree and dominant factor for its adhesion property. Journal of Fluorine Chemistry. 2016;188:139-146. DOI:10.1016/j.jfluchem.2016.06.018

92. Cheng Z, Wu P, Li B, Chen T, Liu Y, Ren M, Wang Z, Lai W, Wang X, Liu X. Surface chain cleavage behavior of PBIA fiber induced by direct fluorination. Applied Surface Science. 2016;384:480-486. DOI:10.1016/ j.apsusc.2016.05.055

93. Nazarov VG, Stolyarov VP, Molchanov SP, Yurasik GA, Artemenko MN. Heterogeneous fluorinecontaining surface macro-, micro-and nanostructures in polymer films and their applications. Polymer Science Series A. 2013;55(11):652-665. DOI:10.1134/ S0965545X13110035

94. Krestinin AV, Kharitonov AP. Covalent functionalization of single-walled carbon nanotubes through the fluorination stage for integration into an epoxy composite. Polymer Science, Series B. 2018;60(4):516-529. DOI:10.1134/S156009041804005X

95. Wang Z, Li S, Li B, Lai W, Liu Y, Cheng Z, Wang $X$, Liu X. The preparation of surface fluorinated polyethylene films with excellent properties similar to that of fluoropolymers. Journal of Fluorine Chemistry. 2017;200:169-178. DOI:10.1016/j.jfluchem.2017.07.003

96. Kruppke I, Bartusch M, Hickmann R, Hund RD, Cherif C. Effects of (Oxy-) fluorination on various high-performance yarns. Molecules. 2016;21(9):1127. DOI:10.3390/molecules21091127

97. Ferraria AM, da Silva JDL, do Rego AMB. XPS studies of directly fluorinated HDPE: problems and solutions. Polymer. 2003;44(23):7241-7249. DOI:10.1016/ j.polymer.2003.08.038

98. Nansé G, Papirer E, Fioux P, Moguet F, Tressaud A. Fluorination of carbon blacks: an X-ray photoelectron spectroscopy study: I. a literature review of XPS studies of fluorinated carbons. XPS investigation of some reference compounds. Carbon. 1997;35(2):175-194. DOI:10.1016/ S0008-6223(96)00095-4

99. Lei YG, Ng KM, Weng LT, Chan CM, Li L. XPS C 1s binding energies for fluorocarbon-hydrocarbon microblock copolymers. Surface and Interface Analysis. 2003;35(10):852-855. DOI:10.1002/sia.1615

100. Clark DT, Dilks A, Thomas HR. ESCA applied to polymers. XXI. Investigation of sample-charging phenomena. Journal of Polymer Science: Polymer Chemistry Edition. 1978;16(7):1461-1474. DOI:10.1002/ pol.1978.170160701

101. Wang F, Zhang T, Li J, Zeeshan KM, He L, Huang Z, He Y. DC breakdown and flashover characteristics of direct fluorinated epoxy/ $\mathrm{Al}_{2} \mathrm{O}_{3}$ nanocomposites. IEEE Transactions on Dielectrics and 
Electrical Insulation. 2019;26(3):702-723. DOI:10.1109/ TDEI.2019.8726018

102. Lv J, Cheng Z, Wu H, He T, Qin J, Liu X. In-situ polymerization and covalent modification on aramid fiber surface via direct fluorination for interfacial enhancement. Composites Part B: Engineering. 2020;182:107608. DOI:10.1016/j.compositesb.2019.107608

103. Kumeeva TY, Prorokova NP. Control of the sorption properties and wettability of a nonwoven polypropylene material by direct gas fluorination. Russian Journal of Applied Chemistry. 2019;92(5):701-706. DOI:10.1134/S1070427219050173

104. Grellmann W, Langer B. Deformation and fracture behaviour of polymer materials. Berlin: Springer International Publishing; 2017. 525p.

105. Xie D, An Z, Xiao H, Zheng F, Lei Q, Zhang Y. Highly hydrophobic and partially conductive polydimethylsiloxane surface produced by direct fluorination and subsequent annealing. IEEE Transactions on Dielectrics and Electrical Insulation. 2015;22(5):29682977. DOI:10.1109/TDEI.2015.005005

106. An Z, Yin Q, Liu Y, Zheng F, Lei Q, Zhang Y. Modulation of surface electrical properties of epoxy resin insulator by changing fluorination temperature and time. IEEE Transactions on Dielectrics and Electrical Insulation. 2015;22(1):526-534. DOI:10.1109/TDEI. 2014.004551

107. Goldstein JI, Newbury DE, Michael JR, Ritchie NW, Scott JHJ, Joy DC. Scanning electron microscopy and X-ray microanalysis. Berlin: Springer; 2017. $550 \mathrm{p}$.

108. Girão AV, Caputo G, Ferro MC. Application of Scanning electron microscopy-energy dispersive X-Ray Spectroscopy (SEM-EDS). Comprehensive Analytical Chemistry. 2017;75:153-168. DOI:10.1016/ bs.coac.2016.10.002

109. Wirti M, Biondo GRR, Romanzini D, Amico SC, Zattera AJ. The effect of fluorination of aramid fibers on vinyl ester composites. Polymer Composites. 2019;40(5):2095-2102. DOI:10.1002/pc.24992

110. Vandi LJ, Truss R, Veidt M, Rasch R, Heitzmann MT, Paton R. Fluorine mobility during SEMEDX analysis: a challenge for characterizing epoxy/ fluoropolymer interfaces. Journal of Physical Chemistry C. 2013;117(33):16933-16941. DOI:10.1021/jp403314t

111. Galuska AA. Quantitative surface analysis of ethylene-propylene polymers using ToF-SIMS. Surface and Interface Analysis. 1997;25(1):1-4. DOI:10.1002/ (SICI)1096-9918(199701)25:1<1::AID-SIA188>3.0.CO;2-R.

112. Briggs D. Analysis of polymer surfaces by SIMS. Part 14. Aliphatic hydrocarbons revisited. Surface and Interface Analysis. 1990;15(12):734-738. DOI:10.1002/ sia. 740151205

113. Briggs D. Recent advances in secondary ion mass spectrometry (SIMS) for polymer surface analysis. British Polymer Journal. 1989;21(1):3-15. DOI:10.1002/ pi.4980210103
114. Van Ooij WJ, Sabata A. Characterization of polymer surfaces and polymer-metal interfaces by static secondary ion mass spectrometry. Surface and Interface Analysis. 1992;19(1-12):101-113. DOI:10.1002/sia. 740190122

115. Huang HL, Goh SH, Lai DM, Huan CHA. ToF-SIMS studies of poly (methyl methacrylate-comethacrylic acid), poly (2,2,3,3,3-pentafluoropropyl methacrylate-co-4-vinylpyridine) and their blends. Applied Surface Science. 2004;227(1-4):373-382. DOI:10.1016/ j.apsusc.2003.12.015

116. Von Gradowski M, Jacoby B, Hilgers H, Barz J, Wahl M, Kopnarski M. ToF-SIMS characterisation of ultra-thin fluorinated carbon plasma polymer films. Surface and Coatings Technology. 2005;200(1-4):334-340. DOI:10.1016/j.surfcoat.2005.02.068

117. Ng KM, Lau YTR, Weng LT, Yeung KL, Chan CM. ToF-SIMS and computation analysis: Fragmentation mechanisms of polystyrene, polystyrene-d5, and polypentafluorostyrene. Surface and Interface Analysis. 2018;50(2):220-233. DOI:10.1002/sia.6361

118. Liu S, Weng LT, Chan CM, Li L, Ho KC, Jiang M. Surface characterization of poly (styrene-co-p-hexafluorohydroxyisopropyl- $\alpha$-methyl styrene) copolymers by ToF-SIMS, XPS and contact angle measurements. Surface and Interface Analysis. 2000;29(8):500-507. DOI:10.1002/1096-9918(200008)29: $8<500::$ AID-SIA893 $>3.0 . \mathrm{CO} ; 2-8$.

119. Kim Y, Kim KJ, Lee Y. Surface analysis of fluorine-containing thin films fabricated by various plasma polymerization methods. Surface and Coatings Technology. 2009;203(20-21):3129-3135. DOI:10.1016/ j.surfcoat.2009.03.039

120. Hinder SJ, Lowe C, Watts JF. ToF-SIMS depth profiling of a complex polymeric coating employing a $\mathrm{C}_{60}$ sputter source. Surface and Interface Analysis. 2007;39(6):467-475. DOI:10.1002/sia.2546

121. Lei YG, Cheung ZL, Ng KM, Li L, Weng LT, Chan CM. Surface chemical and morphological properties of a blend containing semi-crystalline and amorphous polymers studied with ToF-SIMS, XPS and AFM. Polymer. 2003;44(14):3883-3890. DOI:10.1016/S00323861(03)00328-8

122. Chang D, Lorenz M, Burch MJ, Ovchinnikova OS, Hong K, Sumpter BG, Carrillo JMY. Structures of partially fluorinated bottlebrush polymers in thin films. $A C S$ Applied Polymer Materials. 2020;2(2):209-219. DOI:10.1021/acsapm.9b00763

123. Wang L, Yu H, Ullah RS, Haroon M, Fahad S, Li J, Elshaarani T, Khan RU, Nazir A. Recent progress in the electron paramagnetic resonance study of polymers. Polymer Chemistry. 2018;9(24):3306-3335. DOI:10.1039/ c8py00689j

124. Hinderberger D. EPR Spectroscopy. Berlin: Springer; 2011, 67-89 p.

125. Kharitonov AP, Simbirtseva GV, Bouznik VM, Chepezubov MG, Dubois M, Guérin K, Hamwi A, Kharbache H, Masin F. Modification of ultra-high- 
molecular weight polyethylene by various fluorinating routes. Journal of Polymer Science Part A: Polymer Chemistry. 2011;49(16):3559-3573. DOI:10.1002/ pola. 24793
126. Kuzina SI, Kharitonov AP, Moskvin YL, Mikhailov AI. Formation of free radicals in the lowtemperature fluorination of polymers. Russian Chemical Bulletin. 1996;45(7):1623-1627. DOI:10.1007/BF01431798

\section{Информация об авторах / Information about the authors}

Иванов Алексей Алексеевич, начальник Центра коллективного пользования «Физико-химические методы анализа», Национальный исследовательский Томский политехнический университет, Томск, Российская Федерация; ORCID 0000-0001-62711949; e-mail: ivanovaa@tpu.ru

Белов Николай Александрович, кандидат химических наук, начальник лаборатории, Национальный исследовательский Томский политехнический университет, Томск, Российская Федерация; ФГБУН «Ордена Трудового Красного Знамени Институт нефтехимического синтеза им. А. В.Топчиева РАН, Москва, Российская Федерация; ORCID 0000-00023455-9991; e-mail: belov@ips.ac.ru
Alexey A. Ivanov, Head of the core facilities of TPU's "Physical and chemical methods of analysis", National Research Tomsk Polytechnic University, Tomsk, Russian Federation; ORCID 0000-0001-6271-1949; e-mail: ivanovaa@tpu.ru

Nikolay A. Belov, Cand. Sc. (Chemistry), Head of laboratory, National Research Tomsk Polytechnic University, Tomsk, Russian Federation; A.V. Topchiev Institute of Petrochemical Synthesis of Russian Academy of Sciences, Moscow, Russian Federation; ORCID 0000-0002-3455-9991; e-mail: belov@ips.ac.ru

Received 05 April 2021; Accepted 24 May 2021; Published 02 Jule 2021

Copyright: (C) Ivanov AA, Belov NA, 2021. This article is an open access article distributed under the terms and conditions of the Creative Commons Attribution (CC BY) license (https://creativecommons.org/licenses/by/4.0/). 